\title{
PENYALURAN KREDIT USAHA KECIL TERHADAP PENGUSAHA EKONOMI LEMAH
}

\author{
Hasanuddin, Fakhruddin Mansyur, Ulil Amri, Wahidah Rustan
}

Prodi Hukum Ekonomi Syariah Unismuh Makassar || hasanuddiningka@gmail.com

\begin{abstract}
Abstrak
Penelitian ini mengemukakan tentang analisis kualitatif Penyaluran Kredit/Pembiayaan Bank. Dengan fokus masalah yaitu bagaimana penyaluran pembiayaan Tujuan penelitian ini adalah memperoleh data tentang bagaimana penyaluran pembiayaan. Jenis penelitian ini adalah penelitian lapangan (field research) yang bersifat studi kasus dengan menggunakan pendekatan kualitatif deskriptif dan proses penyimpulan hasil penelitian dengan cara berfikir induktif, metode yang digunakan ialah metode kualitatif yaitu strategi meneliti yang lebih banyak memanfaatkan dan mengumpulkan informasi secara mendalam terhadap fenomena yang diteliti. Analisis ini dilakukan dengan cara menelaah dan mengkaji secara mendalam terhadap data yang didapat, sehingga diperoleh kesimpulan yang dapat dipertanggungjawabkan dalam kajian ilmiah. Berdasarkan hasil penelitian di lapangan penyaluran pembiayaan yang dilakukan sudah sesuai dengan prosuder yang ada yaitu berdasarkan peraturan dan ketentuan yang sudah di tetapkan oleh Bank yaitu setiap nasabah yang datang ke bank untuk meminta pembiayaan harus memenuhi semua persyaratan dari Bank.
\end{abstract}

Kata Kunci: Penyaluran, Pembiayaa, Ekonomi Lemah 


\begin{abstract}
This research proposes about qualitative analysis of Credit Distributi / Bank Financing. With the focus of the problem is how the distribution of financing The purpose of this study is to obtain data on how financing disbursement. The type of this research is field research which is case study by using descriptive qualitative approach and the process of conclusion of research result with inductive way of thinking, the method used is qualitative method that is research strategy which more use and collect information deeply to phenomenon investigated. This analysis is done by reviewing and examining deeply to the data obtained, so that obtained conclusions that can be accounted for in scientific studies. Based on the results of research in the field of financing disbursement is done in accordance with the existing prosuder is based on the rules and provisions that have been set by the Bank that every customer who comes to the bank to ask for financing must meet all the requirements of the Bank.
\end{abstract}

Keywords: Distribution, Financing, Weak Economic

\section{PENDAHULUAN}

$\mathrm{P}$ embangunan ekonomi yang terus berlangsung sampai saat ini di Indonesia menuntut berbagai persyaratan untuk mencapai keberhasilan. Pembangunan' ini terlihat dari meningkatnya kegiatan perekonomian yang berdampak langsung terhadap peningkatan usaha dan kebutuhan manusia. Sebagaimana diatur dalam undang-undang, yang dimaksud dengan bank adalah badan usaha yang menghimpun dana dari masyarakat dalam bentuk simpanan, dan menyalurkan dana tersebut kembali kepada masyarakat dalam bentuk kredit atau bentuk lain-lainnya, dalam rangka meningkatkan taraf hidup orang banyak. Dengan demikian, usaha bank di Indonesia tergolong pada jenis-jenis usaha yang umumnya dilakukan oleh bank di banyak negara.

Sebagaimana umumnya negara berkembang, sumber pembiayaan dunia usaha Indonesia masih didominasi oleh penyaluran kredit perbankan yang diharapkan dapat mendorong pertumbuhan ekonomi. Penyaluran kredit memungkinkan masyarakat untuk melakukan investasi, distribusi, dan juga konsumsi barang dan jasa, mengingat semua kegiatan investasi, distribusi, dan konsumsi selalu berkaitan dengan penggunaan uang. Kelancaran kegiatan investasi, distribusi, dan konsumsi ini tak lain adalah kegiatan-kegiatan pembangunan perekonomian masyarakat. 
Pertumbuhan industri perbankan pada era deregulasi menimbulkan maraknya kompetisi kegiatan usaha perbankan dalam menawarkan berbagai jenis inovasi keragaman produknya. Persaingan dalam hal ini menyebabkan industri perbankan berlomba-lomba dalam manghimpun dana dari masyarakat dan menanamkan dana tersebut kedalam pemberian kredit, investasi surat berharga, penyertaan modal, pendanaan perdagangan internasional, serta menempatkan dana pada bank lain.

Perusahaan mempunyai tujuan akhir dari Bank adalah mengusahakan kelangsungan hidup Bank melalui usaha-usaha perbankan yang sehat dan pencapaian keuntungan secara wajar. Artinya dalam operasional suatu Bank (perusahaan) haruslah berusaha sesuai dengan ketentuan-ketentuan yang berlaku. Dan tujuan yang utama pula adalah turut serta dalam membangun dan mengembangkan perekonomian nasional, utamanya adalah peningkatan kesejahteraan masyarakat menengah ke bawah melalui pemberian pembiayaan yang selayaknya.

Bank mempunyai tujuan akhir dari Bank adalah mengusahakan ke- langsungan hidup Bank melalui usahausaha perbankan yang sehat dan pencapaian keuntungan secara wajar. Artinya dalam operasional suatu Bank (perusahaan) haruslah berusaha sesuai dengan ketentuan-ketentuan yang berlaku.

Bank yang mempunyai usaha yaitu membantu masyarakat dalam menyalurkan kredit kepada pengusaha kecil yang membutuhkannya dalam bentuk fasilitas kredit sehingga diharapkan dapat menggerakkan pembangunan sektor riil. Di samping itu Bank juga memiliki core business di bidang pengusaha kecil dalam membantu permodalan untuk meningkatkan usahanya sehingga diharapkan dapat memberikan konsentrasi dalam pembangunan dan margin dari pihak yang terkait.

Oleh karena itu, penulis tertarik untuk mencoba membahas tentang analisis perkembangan penyaluran kredit kepada pengusaha kecil. Karena diantara produk yang ditawarkan bank, kredit bagi pengusaha ekonomi lemah marupakan kredit yang bersekala kecil dan menengah dengan resiko sederhana yang mana apabila terjadi wanprestasi 
akan mendatangkan kerugian bagi berkelebihan uang disebut pemberi Bank.

Kegiatan usaha perbankan yang kredit dan yang membutuhkan uang disebut penerima kredit. Bilamana lazim dan paling banyak memang terjadi pemberian kredit berarti pihak peranannya dalam menanamkan dana yang memelukan uang berjanji akan adalah penyaluran kredit ke- masyaramengembalikan uang tersebut dalam kat. Pengertian kredit itu sendiri mempunyai dimensi yang beraneka ragam, dimana banyak ahli memberikan pengertian yang berbeda-beda baik dalam memberikan gambaran tentang bentuk maupun corak dari kredit.

Dengan demikian pengertian suatu jangka waktu tertentu pada masa yang akan datang disini terdapat tenggang waktu antara pemberi prestasi dengan penerima kembali restasi.

Lukman Dendawijaya dalam khusus kredit, menurut UU No.10 bukunya Manajemen Perbanakan (2001:92) Dasar-dasar perbankan, Tahun 1998 yaitu meminjamkan uang atau tagihan yang dapat dipersamakan analisis kredit atau penilaian kredit adalah suatu proses yang dimaksudkan dengan itu, berdasarkan perjanjian untuk menganalisis atau menilai suatu tertulis baik dibawah tangan maupun permohonan kredit yang diajukan dihadapan notaris dari berbagai pengamanan maka debitur akan oleh calon debitur kredit sehingga dapat memberikan keyakinan kepada menyerahkan suatu jaminan baik yang berupa kebendaan maupun yang bukan kebendaan, dan pihak debitur berkewajiban untuk melunasi utangnya pihak bank bahwa proyek yang akan dibiayai dengan kredit bank cukup layak (Feasible).

Analisis kredit adalah kajian yang setelah jangka waktu tertentu di dilakukan untuk mengetahui kelayakan masa mendatang dengan balas prestasi yaitu berupa pemberian bunga.

Selanjutnya, pemberian kredit dari suatu permasalah kredit. Melalui analisis kredit, dapat diketahui apakah usaha nasabah layak (feasible), marketable (hasil usaha dapat terdapat dua pihak yang ber- dipasarkan), profiteble (menguntungkepentingan, yaitu pihak yang kan), dan bankable (memenuhi 
berbagai persyaratan bank), serta dapat dilunasi tepat waktu. Pembentukan analis kredit ini didasarkan pada asas perbankan Indonesia untuk melakukan prinsip kehati-hatian yang terutang dalam pasal 2 Undang-Undang No.10 Tahun 1998 yang menjelaskan bahwa perbankan dalam melakukan usahanya harus berasas demokrasi ekonomi dan tepat menerapkan prinsip kehati-hatian. Pelaksanaan analis kredit berpedoman pada Undang-Undang No.10 Tahun 1998 pada pasal 1 ayat 11 , pasal 8 , dan pasal 29 ayat 3 .

Adapun prinsip dasar dalam menganalisis kredit menurut Veithzal dan Audria (2007:289), yaitu:

1. Character: Character adalah keadaan watak/sifat dari nasabah, baik dalam kehidupan pribadi maupun dalam lingkungan usaha.

2. Capital: Capital adalah jumlah dana/modal sendiri yang dimiliki oleh calon nasabah.

3. Capacity: Capacity adalah kemampuan yang dimiliki calon nasabah dalam menjalankan usahanya guna memperoleh laba yang diharapkan.

4. Collateral: Collateral adalah barang-barang yang diserahkan oleh nasabah sebagai agunan terhadap kredit yang ditrimanya.

5. Condition of Economic: Condition of Ekonomic yaitu setuasi dan kondisi politik, sosial, ekonomi, budaya yang mempengaruhi keadaan perekonomian pada suatu saat yang kemungkinannya mempengaruhi kelancaran perusahaan calon debitur.

6. Constraint: Constraint adalah batas dan hambatan yang tidak memungkinkan suatu bisnis untuk dilaksanakan pada tempat waktu.

\section{METODE PENELITIAN}

Penelitian ini dilakukan di salah satu Bank di Makassar. Jenis penelitian ini adalah penelitian lapangan (field research), yaitu yang bersifat studi kasus, yakni penulis langsung melakukan penggalian data kepada semua pegawai yang berhubungan dengan pembiayaan.

Sifat studi kasus penelitian ini adalah deskriptif yaitu penelitian yang berusaha untuk menuturkan pemecahan masalah yang ada berdasarkan data-data hasil dari wawancara dengan responden dan menganalisis dari data tersebut.

1. Data

Data yang akan digali dalam penelitian ini meliputi:

a. Identitas responden, meliputi: nama, umur, pendidikan, pekerjaan, lama bekerja dan alamat 
b. Mekanisme dan perolehan pembiayaan, Informasi dari kepala kantor dan pegawai Bank tentang mekanisme dan perolehan penyaluran pembiayaan.

c. Kendala yang dihadapi dalam pelayanan pembiayaan

2. Sumber data

$$
\text { Sumber data dalam }
$$
penelitian ini adalah pimpinan dan pegawai Bank itu sendiri dan dokumen yang berkaitan dengan penyaluran pembiayaan.

Dalam rangka memperoleh dan mengumpulkan data dilapangan, maka teknik yang digunakan adalah teknik wawancara dan dokumen penyaluran pembiayaan, yaitu penulis melakukan dialog langsung kepada pimpinan dan pegawai Bank yang dijadikan informen, sehingga dapat diperoleh data mengenai permasalahan yang diteliti.

\section{Tekhnik Pengolahan Data}

Setelah data terkumpul, selanjutnya dilakukan pengolahan data dengan melalui beberapa tahapan sebagai berikut:

a. Editing, yaitu memeriksa dan menelaah kembali terhadap datadata yang terkumpul dari reponden, untuk mengetahui kekurangan dan kelengkapannya, sehingga dapat diadakan

penggalian lebih lanjut bila diperlukan, agar dapat melanjutkan hal tersebut ketahap penyempurnaan.

b. Kategorisasi, yaitu melakukan pemilahan terhadap data yang sudah diedit berdasarkan permasalahannya, sehingga tersusun secara sistematis.

2. Analisis data

Anlisis yang digunakan dalam penelitian ini adalah analisis kualitatif, yaitu strategi meneliti yang lebih banyak memanfaatkan dan mengumpulkan informasi secara mendalam terhadap fenomena yang diteliti. Analisis ini dilakukan dengan cara menelaah dan mengkaji secara mendalam terhadap data yang didapat, sehingga diperoleh kesimpulan yang dapat dipertanggungjawabkan dalam kajian ilmiah.

Agar penelitian ini dapat tersusun secara sistematis, maka ditempuhlah tahapan-tahapan sebagai berikut:

1. Tahap Pendahuluan: Pada tahap ini, penulis mempelajari dan menelaah secara intensif terhadap subyek dan obyek yang diteliti dan selanjutnya dituangkan dalam desain operasional.

2. Tahap Pengumpulan Data: Pada tahap ini penulis terjun kelapangan

48 | Penyaluran Kredit Usaha Kecil terhadap Pengusaha Ekonomi Lemah 
dengan melakukan menghimpun data dari para responden, sehingga diperoleh data secara jelas berkaitan dengan mekanisme dan perolehan yang didapat dalam penyaluran pembiayaan di Bank.

3. Tahap Pengolahan dan Analisi Data: Setelah data hasil penelitian yang diperlukan terkumpul, kemudian diolah sesuai dengan teknik pengolahan data, untuk memperoleh sejumlah kesimpulan mekanisme, perolehan serta kendala yang dihadapi dalam penyaluran pembiayaan, maka penulis menganalisis secara obyektif dengan pedoman pada landasan teoritis yang telah disusun.

4. Tahap Penyusunan/ penyempurnaan: Pada tahap ini penulis melakukan penyusunan seluruh berdasarkan sistematika yang ada.

\section{HASIL DAN PEMBAHASAN}

\section{Gamabran Umum Perbankan}

Menurut UU RI No 10 Tahun 1998 tanggal 10 November 1998 tentang perbankan, dapat disimpulkan bahwa usaha perbankan meliputi tiga kegiatan, yaitu:

1. Menghimpun dana

2. Menyalurkan dana

3. Memberikan jasa bank lainnya

Kegiatan menghimpun dan menyalurkan dana merupakan kegiatan pokok bank sedangkan memberikan jasa bank lainnya hanya kegiatan pendukung. Kegiatan menghimpun dana, berupa mengumpulkan dana dari masyarakat dalam bentuk simpanan giro, tabungan, dan deposito:Biasanya sambil diberikan balas jasa yang menarik seperti, bunga dan hadiah sebagai rangsangan bagi masyarakat. Kegiatan menyalurkan dana, berupa pemberian pinjaman kepada masyarakat. Sedangkan jasa-jasa perbankan lainnya diberikan untuk mendukung kelancaran kegiatan utama tersebut. Bank didirikan untuk beberapa manfaat perbankan dalam kehidupan.

Terlepas dari funsi-fungsi perbankan (bank) yang utama atau turunannya, maka yang perlu diperhatikan untuk dunia perbankan, ialah tujuan secara filosofis dari eksistensi bank di Indonesia. Hal ini sangat jelas tercermin dalam Pasal empat (4) Undang-Undang Nomor 10 Tahun 1998 yang menjelaskan, "Perbankan Indonesia bertujuan menunjang pelaksanaan pembangun-an nasional dalam rangka meningkatkan pemerataan, per-tumbuhan ekonomi, dan stabilitas nasional ke arah peningkatan kesejahteraan rakyat 
banyak". Meninjau lebih dalam terhadap kegiatan usaha bank, maka bank (perbankan) Indonesia dalam melakukan usahanya harus didasarkan atas asas demokrasi ekonomi yang menggunakan prinsip kehati-hatian. Hal ini, jelas tergambar, karena secara filosofis bank memiliki fungsi makro dan mikro terhadap proses pembangunan bangsa.

\section{Penyaluran Kredit Kepada Nasabah}

Hasil Wawancara dengan salah satu pegawai/karyawan bank di kota Makassar. Hal ini, dapat di uraing dengan jelas terkait penyaluran kredit kepada masyarakat.

Penyalur/pemberi Kredit Bank dalam kegiatannya tidak hanya menyimpan dana yang diperoleh, akan tetapi untuk pemanfaatannya bank menyalurkan kembali dalam bentuk kredit kepada masyarakat yang memerlukan dana segar untuk usaha. Tentunya dalam pelaksanaan fungsi ini diharapkan bank akan mendapatkan sumber pendapatan berupa bagi hasil atau dalam bentuk pengenaan bunga kredit. Pemberian kredit akan menimbulkan resiko, oleh sebab itu pemberiannya harus benar-benar teliti.

\section{Agent Of Trust}

Yaitu lembaga yang landasannya kepercayaan. Dasar utama kegiatan perbankkan adalah kepercayaan (trust), baik dalam penghimpun dana maupun penyaluran dana. Masyarakat akan mau menyimpan dana dananya di bank apabila dilandasi kepercayaan. Dalam fungsi ini akan di bangun kepercayaan baik dari pihak penyimpan dana maupun dari pihak bank dan kepercayaan ini akan terus berlanjut kepada pihak debitor. Kepercayaan ini penting dibangun karena dalam keadaan ini semua pihak ingin merasa diuntungkan untuk baik dari segi penyimpangan dana, penampung dana maupun penerima penyaluran dana tersebut.

\section{Agent Of Development}

Yaitu lembaga yang
memobilisasi dana untuk

pembangunan ekonomi. Kegiatan bank berupa penghimpun dan penyalur dana sangat diperlukan bagi lancarnya kegiatan perekonomian di sektor riil. Kegiatan bank tersebut memungkinkan masyarakat melakukan kegiatan investasi, kegiatan distribusi, serta 
kegiatan konsumsi barang dan jasa, mengingat bahwa kegiatan investasi, distribusi dan konsumsi tidak dapat dilepaskan dari adanya penggunaan uang. Kelancaran kegiatan investasi, distribusi, dan konsumsi ini tidak lain adalah kegiatan pembangunan perekonomian suatu masyarakat.

\section{Agent Of Services}

$$
\text { Yaitu lembaga yang }
$$
memobilisasi dana untuk pembangunan ekonomi. Disamping melakukan kegiatan penghimpun dan penyalur dana, bank juga memberikan penawaran jasa perbankan yang lain kepada masyarakan. Jasa yang ditawarkan bank ini erat kaitannya dengan kegiatan perekonomian masyarakat secara umum.

$$
\text { Penyaluran pembiayaan }
$$
kepada masyarakat dilakukan dengan pemberian dana dengan angka yang sedikit agar masyarakat tidak terbebani dengan angsuranya karena pembiayaan sedikit berarti angsuranya juga sedikit. Hal ini memberikan dampak yang positif kepada masyarakat khususnya masyarakat ekonomi lemah yang dapat memanfaatkan produk-produk ini, karena angka diberikan sedikit dan syarat yang deberikan pula mudah, dengan demikian dapat meningkatkan pengembangan usahanya bagi pelaku ekonomi lemah.

Produk - produk yang ditawarkan kepada masyarakat ekonomi lemah guna meningkatkan taraf hidupnya melalui pembiayaan ini, di upayakan produk yang memiliki keringanan kepada masyarakat sehingga masyarakat tidak terbebani dengan angsuran yang harus dibayar.

Setiap calon nasabah yang ingin mengajukan pembiayaan harus memenuhi persyaratan yang ditentukan oleh bank, apabila sudah sesuai maka nasabah akan mengisi formulir permohonan pembiayaan dan melengkapi persyaratan yang diajukan oleh pihak bank. Adapun persyaratan yang harus dimiliki dan dilengkapi oleh calon nasabah adalah:

1. Surat Permohonan Pembiayaan

2. Foto Copy suami istri

3. Foto Copy KK

4. Rencana Anggaran Biaya 
Ini adalah syarat sederhana yang diberikan kepada nasabah untuk memudahkan dalam proses pembiayaan karena jika prosesnya rumit maka masyarakat akan berfikir untuk melakukan pembiayaan di bank tempat kami bekerja.

Analisis kelayakan pembiayaan yang dilakukan oleh Bank, ternyata juga berpegangan pada analisis teori $5 \mathrm{C}$ yang mana mereka pertama, menganalisis watak nasabah yaitu dengan mengunjungi tempat nasabah untuk memastikan tempat tinggal nasabah. Misalnya nasabah ingin melakukan pembiayaan untuk meluaskan usaha mereka maka pihak bank datang untuk memantau usaha apa yang nasabah lakukan untuk memastikan bahwa nasabah tidak berbohong dan lain sebagainya. Kedua, pihak bank juga melakukan penilaian kemampuan terhadap calon nasabahnya dalam melakukan usaha yang telah digeluti calon penerima pembiayaan dari Bank sehingga pihak bank yakin bahwa usaha yang akan dibiayai tepat sasaraan.
Ketiga, pihak bank juga melihat modal usaha calon penerima fasilitas pembiayaan mereka yaitu dengan cara melihat posisi keuangan calon nasabah secara keseluruhan, seperti modal awal nasabah, laba rugi yang didapatkan oleh nasabah setiap hari atau setiap bulannya, selain itu pihak bank juga bertanya dan mengumpulkan informasi tentang nasabah dengan orang-orang disekitar calon nasabah tersebut. Keempat, pihak bank juga sudah menetapkan nilai agunan bagi calon nasabah. Kelima, pihak bank juga melakukan survey terhadap usaha yang akan dijalankan nasabah apakah usaha tersebut akan tetap berjalan dengan lancar selama proses pembiayaan berlasung ataukah hanya bertahan sebentar saja sehingga mengakibatkan kerugian yang sangat dihindari oleh pihak bank.

Analisis pembiayaan ini dilakukan guna menghindari halhal yang akan merugikan pihak bank nantinya oleh karena itu bank sangat selektif dalam pemberian fsilitas pembiayaan terhadap calon nasabah mereka. 
Kendala-Kendala yang dihadapi

Dapat diuraikan hasil wawancara terkait kedala yang dihadapi salah satu bank yang menjadi informen peneliti yaitu:

1. Kurang terbukanya atau kurang lengkapnya informasi yang diberikan nasabah pada saat proses pembiayaan.

2. Pembiayaan yang diberikan digunakan tidak sesuai dengan peruntukan yang diperjanjikan dalam akad pembiayaan, terjadi mismanagemen pada usaha yang dijalankan nasabah

3. Nasabah yang melakukan pembiayaan menunggak dan usahanya kurang lancar.

4. Kondisi keuangan nasabah memburuk, manajemen tidak memiliki kemampuan prima dalam mengelolah perusahaan

5. Nasabah tidak memiliki itikad baik dalam menyelesaikan kewajiban, penerapan goo corporate governance pada debitur lemah

6. Kemudian permasalah eksternal diluar bank ataupun nasabah dapat menimbulkan masalah yaitu

a. Kondisi makro perekonomian kurang kondusif yang dapat mempengaruhi dunia usaha secara menyeluruh

b. Regulasi domestik dan internasional yang dapat mempengaruhi usaha-usaha tertentu yang dapat berjalan , fluktuasi suku bunga bank masih menjadi pertimbangan dan alasan masyarakat dalam transaksi pembiayaan

Secara deserhadanya dijelaskan bahwa seperti ini kedala yang dihadapi pembiayaan kepada masyarakat atau pengusaha ekonomi lemah, sehingga memerlukan penaganan yang serius untuk meningkatkan mtifasi masyarakat dalam mengembangkan usahanya.

\section{Rancangan Tahapan Berikutnya}

Berdasarkan hasil analisis kedala yang dihadapi bank dalam pembiayaan, setelah di analisis ternya kedala yang dihadapi bank dalam pembiayaan berpotensi banyak pada nasabah yang tidak sesuai permohonan dan realisasnya sehingga mengalami penunggakan yang berkelanjuta, hingga akhirnya menjadi kredit macet.

$$
\text { Untuk selanjutnya akan }
$$
dilakukan penelitian lanjutan untuk 
lebih mengetahui proses yang masyarakat dalam artian bahwa pihak dilakukan perbankan dalam bank dan nasabah sama-sama memproses nasabah yang melakukan menjalangkan fungsinya bank sebagai pembiayaan tapi tidak sesuai dengan penyedia dana dan nasabah sebagai realitas penggunaan dananya, hal ini debitur yang menggunakan dana dapat mempengaruhi nasabah ataupun tersebut. Pembiayaan kepada calon nasabah dalam melakukan masyarakat ekonomi lemah merupakan pembiayaan pada bank.

\section{KESIMPULAN}

Penyaluran kredit usaha kecil kepada masyarakat ekonomi lemah dilakukan dengan mitra dengan konsep pada salah satu bank di Makassar untuk memudahkan masyarakat dan mendukung keberlanjutan usaha bagi masyarakat ekonomi lemah agar lebih serius mengembangkan usahanya.

\section{DAFTAR PUSTAKA}

Dendawijaya Lukman. 2001. Manajemen Perbankan. Jakarta: Ghalia Indonesia. Hasanuddin Rahman. 2000. Kebijakan Kredit Perbankan Yang Berwawasan Lingkungan, PT. Citra Aditya.

Kasmir.1999. Bank \& Lembaga Keuangan Lainnya. Jakarta: PT. Raja Grafindo.

Malayu Hasibua, Aagustus. 2004. Dasar-dasar Perbankan. Cet. III; Jakarta: PT.Bumi Aksara.

Simorangkir, O.P. 2001. Dasar-Dasar Mekanisme Perbankan. Jakarta: Aksara Press.

Sinungan Muchdarsyah. 2003. Strategi Manajemen Bank. Jakarta: Rineka Cipta.

Suyatno, Thomas. 2000. Masalah Kelembagaan Perbankan, Ed. ke-V, Cet. VIII; Yogyakarta: Erlangga.

Syaefuddin, A.M. 2002. Manajemen Perkreditan Bank Komersil. Yogyakarta: Erlangga.

Tahir, A. Kaslan. 2000. Bank dan Lembaga Keuangan Lainnya, Edisi Revisi, Yogyakarta, Bagian penerbit Fakultas Ekonomi Universitas Islam Indonesia. 